Published in final edited form as:

Front Biosci. ; 12: 174-191.

\title{
Mechanotransduction in skeletal muscle
}

\author{
Thomas J. Burkholder \\ School of Applied Physiology, Georgia Institute of Technology, Atlanta, Georgia 30332
}

\begin{abstract}
Mechanical signals are critical to the development and maintenance of skeletal muscle, but the mechanisms that convert these shape changes to biochemical signals is not known. When a deformation is imposed on a muscle, changes in cellular and molecular conformations link the mechanical forces with biochemical signals, and the close integration of mechanical signals with electrical, metabolic, and hormonal signaling may disguise the aspect of the response that is specific to the mechanical forces. The mechanically induced conformational change may directly activate downstream signaling and may trigger messenger systems to activate signaling indirectly. Major effectors of mechanotransduction include the ubiquitous mitogen activated protein kinase (MAP) and phosphatidylinositol-3' kinase (PI-3K), which have well described receptor dependent cascades, but the chain of events leading from mechanical stimulation to biochemical cascade is not clear. This review will discuss the mechanics of biological deformation, loading of cellular and molecular structures, and some of the principal signaling mechanisms associated with mechanotransduction.
\end{abstract}

\section{Keywords}

Skeletal muscle; mechanotransduction; stretch

\section{INTRODUCTION}

The detection and response to physical forces is essential to all cells, but is particularly relevant to those that play a fundamentally mechanical role. The primordial nature of the cellular interaction with the physical world suggests that its control should be highly regulated and specific, and that the response should integrate many aspects of cellular physiology. Pathways involved in detecting and producing forces in muscle overlap those involved in detecting nutrient availability $(1,2)$, intracellular energy status $(3,4)$, and oxidative status $(5,6)$. The signaling pathways modulated by force, insulin and insulin-like growth factor I (IGF-I)(7), adenosine monophosphate (AMP) dependent kinase (AMPK) (8), reactive oxygen species (ROS) (9), and prostaglandins (PG) (10) seem intractably intertwined.

The adaptations of skeletal muscle to mechanical signals have been widely described, and the interested reader is referred to several recent reviews (11-14). The physiological increase in force generating capacity associated with activity, and the increase in flexibility associated with stretch, were recognized in antiquity, but the mechanisms by which those changes manifest are still unclear. The present intention is to consider the shape changes and forces associated with mechanical signals and juxtapose them with observed changes in biochemical signaling to determine what might contribute to the cellular perception of mechanical signals.

Careful consideration of the mechanical environment is the first step to sort out that labyrinth of signaling. When one considers mechanisms by which the mechanical environment can be

Address for Correspondence: Thomas J. Burkholder, School of Applied Physiology, Georgia Institute of Technology, 281 Ferst Dr., Weber 113, Atlanta, GA 30332, thomas.burkholder@hps.gatech.edu, (404) 894-1029 
sensed, it is common to think of "force" and "deformation" separately. Sometimes this distinction is legitimate, but sometimes it may mask an underlying physical relationship. An elastic steel spring has a fixed relationship between force and deformation: to obtain any desired deformation, the force is exactly specified, and to obtain any desired force, the deformation is exactly specified. In contrast, the shape of viscoelastic polymers, such as Gortex or Silly Putty, depends on both the applied force and for how long that force is applied. Biological tissues can exhibit both kinds of behaviors.

This separation between "force" and "deformation" is reinforced in skeletal muscle because of the special property of an active contractile matrix. The active state means a muscle fiber may have the same shape while being subject to a range of external forces. As with man-made mechanical systems, some of the molecules and structures within the cell will have a conformation defined by the shape of the cell, while the conformation of other molecules will be influenced by the loading state, even if the whole cell is forced to retain the same shape. The level of active force generation in a muscle fiber depends on intracellular calcium (15), but the contractile matrix is anchored to the extracellular matrix through a network of extensible intermediate filaments, adhesion molecules, and accessory proteins $(14,16)$. During force generation, shortening of the contractile matrix may occur at the expense of lengthening of elements of the anchoring network.

Increased force is not the only feature of the active state. Generation of active tension requires a tremendous expenditure of chemical energy and consequently alters the concentrations of potent regulators of cell function, including adenosine mono- and tri-phosphate (AMP, ATP), ROS, and tricarboxylic acid (TCA) cycle intermediaries (17). Force generation is regulated by calcium and can increase the intracellular concentration of this ubiquitous regulator by 100 fold. The complex relationships among muscle shape, force, metabolic status, and calcium status make it very difficult to abstract mechanotransduction from the larger context of the cell. It is important to recognize exactly what aspects of "force" are really involved in any particular observation. This review will examine the pathways of force transmission, the consequent cellular and molecular deformations, and attendant signaling mechanisms. Points of interaction with other major signaling mechanisms will be highlighted.

\section{APPLICATION OF DEFORMATION}

\subsection{Mechanical Concepts}

To most clearly describe the mechanics of cellular deformation, this review will use the rigorous definitions for mechanical concepts. This terminology carries specific meanings that may differ slightly from conversational use, and it is worthwhile to express the specific meanings intended. A force is a load applied to a structure and has units of Newtons (N). A stress is a force normalized to the area over which it acts and has units of Newtons per square meter, or Pascals $(\mathrm{Pa})$. This means that both a force and a surface are required to define a stress, which has the important consequence that the force (or its components) can be either perpendicular to the surface or in the plane of the surface. The component of force perpendicular to the surface on which it acts generates a tensile or compressive stress, depending on direction, while components of force within the plane of the surface generate shear stresses.

The distinction between shear and tensile stress is important. Tensile loading and tensile strength are straightforward, familiar concepts. Ropes are loaded in tension and derive their strength from the tensile strength of the constituent fibers. That rope derives its flexibility from the ability of those stiff fibers to slide relative to each other. The arrangement of rope fibers results in a structure that is strong in tension because of the strength of individual fibers, but weak in shear because of the lack of connection between adjacent fibers. The connective tissue 
and adhesions that anchor a cell are relatively strong in shear, but relatively weak in tension, making myofibers easier to separate by peeling than by sliding $(18,19)$.

Deformation is a gross change in shape of an object and has units of meters $(\mathrm{m})$, or more commonly in cellular systems, some very small fraction thereof. Strain is a deformation normalized to the starting dimension of the object and technically has no units, although it is common to express it in "microstrains" $\left(10^{-3} \mathrm{~m} / \mathrm{m}\right)$ or "percent" $\left(10^{-2} \mathrm{~m} / \mathrm{m}\right)$. The most familiar strain results from a tensile stress and appears as a change in length of the object. Strain resulting from shear stress causes a twisting deformation that is generally described as a change in angle, meaning that a square in the resting condition becomes a parallelogram under shear stress. Shear strains are associated with a change in shape without any change in volume. Many materials, including muscle, deform with constant volume. If muscle is subjected to tension in one direction, it develops internal stresses that cause constriction in the perpendicular plane. Conversely, compressive stresses in the transverse plane will develop internal stresses that cause lengthening.

Tissues only deform in response to some force, either internally or externally applied, and it is important to consider exactly what forces act on a muscle or muscle cell and the pathway by which those forces act on the cell. Both the deformation and the route of force application may differ dramatically between intact muscles and isolated or cultured fibers.

\subsection{Models of mechanical stimulation}

The methods that can be used to deform or apply force to muscle cells are nearly limitless, but this review will concentrate on three of the most common themes. The most important method of deformation is that which occurs in vivo, in the intact system, which will be referred to as "in vivo." The in vitro model that is likely to most closely mimic this deformation is an isolated muscle preparation, which will be referred to as "isolated muscle." Culture systems of immature myotubes derived from muscle precursor cells and maintained on an elastic substrate are common models and will be referred to as "culture models." Also of note, but not to be considered in the present work, are single fibers isolated either by enzymatic dissociation or microdissection, which lack the homogenizing influence of neighboring cells or substrate, and three-dimensional cultures derived from muscle precursor cells embedded in an extensive manmade matrix, and the properties of the matrix may dominate the mechanical response.

The in vivo system is quite complex. Any particular muscle is subject to loads imposed through its tendons, through distributed attachments to bone, through pressures imposed by contact with bone, fascial structures, and other muscle, and through connective tissue adhesions to adjacent tissues, recently referred to as myofascial force transmission $(20,21)$. The details of deformation under these conditions will vary widely among muscles, will depend on the condition, i.e. activation, of nearby muscles, and is essentially intractable. Limited direct measurement of muscle deformation during force generation, generally limited to two dimensional analysis, demonstrates this complexity $(22,23)$. To generalize grossly, a muscle in vivo will be subject to substantial transverse and bending loads not present in isolation, in addition to the loads and deformations of a muscle in isolation, all of which may be amplified or attenuated by shear stresses from association with adjacent tissues.

While individual fibers generally shorten during force generation, they may also twist and rotate $(24,25)$. The deformations within the whole muscle have been extremely difficult to quantify directly, although experimental observations are beginning to appear $(23,24)$. Several authors have presented continuum or finite element models of muscle during force generation (26-29). Each of these models confirms that the distribution of deformation within a muscle is not uniform and that shear strains, both parallel and perpendicular to the fiber axis, contribute to the overall deformation (Figure 1). 
The loading mode that comes to mind most rapidly in muscle is the loading induced by active force generation. Force generated by the action of actin and myosin is aggregated by the rigid attachments at the Z-disks, and the Z-disks are tied into the cytoskeleton both along and perpendicular to the fiber axis $(30,31)$. While there are clear morphological specializations at the myotendinous junction that suggest it plays an important role in transmitting that force to the extracellular matrix (ECM) and tendon $(32,33)$, it is also clear that transmission of force by shear, often referred to as "lateral force transmission," contributes to whole muscle force transmission $(19,34)$. The presence of elastic tissue, whether tendon, aponeurosis, or perimysium, in series with the contractile tissue means that active force generation will result in myofiber shortening during fixed endpoint activations $(35,36)$, and potentially during lengthening activations $(37,38)$. This means that nominally isometric activations are associated with negative, or compressive, strain relative to the passive condition and highlights the care required in deciphering force and stretch in muscle. It is quite possible for "stretch" during a high-force generation to be associated with a decrease in length, while to produce similar force levels in a passive muscle requires an extreme stretch, often beyond the physiological range.

Compressive loads may participate in the deformation, particularly of relaxed muscle. While titin is widely recognized as a major contributor to the stiffness of isolated fibers, its contribution to whole muscle stiffness is less clear (39). The mechanical properties of intramuscular connective tissue are particularly difficult to determine, making the distribution of passive tension between passive myofibers and matrix nearly impossible to estimate (40-42). The structure of that passive matrix is a woven network of stiff collagen fibrils, and the mechanical behavior of relaxed muscle is consistent with reorientation of that matrix around isovolumic myofibers $(42,43)$, suggesting that the transfer of load to passive muscle fibers may be analogous to a Chinese Finger Trap. This mechanism is the foundation of the McKibben "artificial muscle" that uses a fabric mesh to convert pressure in an inflatable bladder to tension $(44,45)$, and Galen proposed it as the mechanism of muscle action nearly 2000 years ago. The relevance of this mechanism to the present topic is that it suggests that fibers may undergo lengthening deformation resulting from transverse compressive forces, rather than tension or shear on molecular adhesions. It is also worth noting that this is an illustration of "tensegrity," the idea that local changes in the shape of a structure depend on the global integration of that structure $(46,47)$.

The principal feature that distinguishes whole muscle from cultured myotubes is the integration with a three dimensional (3-D) extracellular matrix and extensive connections among adjacent fibers. This mechanical integration has the effect of homogenizing deformations, meaning that gradients in shape changes will be smaller than they might be in an isolated fiber. A whole muscle is much more like a fiber-reinforced composite than it is like a bundle of spaghetti $(19,42)$. The mechanical properties of the whole muscle will be influenced by the volume fractions and properties of ECM, passive fibers and active fibers. Along the axis of fibers, a materials science analysis suggests that the tension borne by each group will be in proportion to its stiffness and volume fraction (48), which means that very little tension will be transmitted to the passive fibers within a partly activated muscle. It is even possible, due to the intramuscular pressure generated by the active fibers (28), that the principal load borne by the passive fibers is a transverse compression, rather than an axial tension.

The culture loading models differ from in vivo and isolated muscle loading in both biological and geometric aspects. Cell adhesions are dynamic, and remodeling of those adhesions may contribute to rapid relaxation of cells subjected to static stretch in culture (49). While this remodeling is not unique to culture models, the freedom of the fiber to move relative to its attachments is. Further, force is transmitted from a muscle fiber to the surrounding tissue across its entire surface, where force is transmitted to a cultured cell only along the basal surface through its attachment to the substrate, which may cause a steep gradient in shear stress not 
present in whole muscle. An adherent cell will rapidly contract if those adhesions are disturbed, suggesting that the substrate sustains a high tension on even nominally resting cultures, an observation that supports the tensegrity model of cellular structure (47). Cultures maintained for any length of time will synthesize and assemble their own ECM (50), but the structure of this matrix and its role in stabilizing the cell during deformation is not clear. In fact, the 3 dimensional deformation to which a cell is subjected during deformation of its substrate is not clear.

Various cell culture systems are attractive models in which to study mechanotransduction, and the route by which force and deformation are transmitted to adherent cells is relatively clear. Cells growing on the surface of an elastic membrane adhere to that membrane via adhesion molecules (dystroglycan, integrins, etc.) that link the cytoskeleton to ECM molecules adhered to the membrane. Deformation of the membrane moves the ECM molecules, which imposes a shear force on the adhesion molecules, and tension in the cytoskeleton, to deform the cell. This is an attractive model, because it mimics one's expectation of the force transmission pathways followed during force generation in a whole muscle.

The substrate to which cultured cells adhere is dramatically more stiff than the cells themselves. This stiffness mismatch means that the deformation is determined by the substrate, rather than the cells, and culture based loading systems, including uniaxial systems, constrain both dimensions of the adherent surface, which may move dramatically differently than an in vivo or isolated muscle deformation. In culture, the basal surface undergoes very much the same deformation as the elastic substrate (Figure 1), but the media facing surface, which experiences no shear stress, may be different. For the cell to remain isovolumic during stretch, it must contract along its only free dimension. This is a sharp contrast to stretch in vivo, in which the surrounding cells poorly resist transverse constriction, resulting in deformation that is specified in one dimension, but relatively free in the orthogonal plane. Cells subjected to stretch in a 2 dimensional culture system can be expected to be subject to unusual transverse strains.

Common loading paradigms in culture can be divided into uniaxial and biaxial, including the special case of equibiaxial, tension based on major applied deformation. Uniaxial systems apply stretch along nominally one axis, generally by pulling on the ends of a sheet of silicone rubber. If the edges of the substrate are not constrained, the internal stresses developed in the substrate cause transverse constriction and may induce a shear strain as well (51). If the material properties of the substrate do not match those of the adherent cells, the transverse constriction of the membrane will impose a transverse stress on the cell in addition to the nominal uniaxial stress. Myotubes are transversely isotropic, meaning that they are different along their long axis than across their diameter, and one might expect a different cellular response to strain along rather than across that axis (52). Biaxial systems apply large deformations in two dimensions, often by applying pressure to a silicone membrane fixed like a drumhead. The deformation in this case can be quite complex (53) and may vary over the culture surface. In the special case where pressure is applied by a large, flat indenter, deformations are equal in both the radial and tangential direction and the pattern is referred to as equibiaxial (54). Equibiaxial deformations have the special feature of being without orientation in the plane, so that a myotube adhered with any direction is subject to the same shape change.

\section{CELLULAR DEFORMATION}

A cellular or molecular deformation is the critical event comprising mechanotransduction. In order to signal a mechanical perturbation, there must be something that undergoes a change associated with the perturbation. This sounds like a trivial observation, but it provides a framework from which to consider potential sensors. The most obvious mechanical changes in skeletal muscle are associated with adhesive complexes and the contractile apparatus, but 
the sarcolemma and cytoskeleton deform as well, and specific molecules are likely to be subject to load-induced stretch.

The molecular pathways by which force is transmitted from the ECM to the cytoskeleton and contractile apparatus have been reviewed at length elsewhere $(16,19)$. Force transmission is typically considered to occur primarily through specialized structures, the costameres or focal adhesions, that are rich in both adhesion and signaling molecules $(55,56)$. The principal adhesion molecules in skeletal muscle are dystroglycan and integrin, both of which are laminin receptors $(57,58)$. Binding of dystroglycan or integrin to their ECM targets simultaneously nucleates the condensation of the focal adhesion plaque and the polymerization of the ECM network $(57,59)$. The adhesion plaques connect to the contractile matrix through a network of intermediate filaments (16), although the contractile matrix generally develops poorly in culture models. An extensive network of biochemical signaling, including mitogen activated protein kinases (MAPKs) and phosphatidylinositol 3' kinase (PI-3K), is associated with integrin ligation $(46,60)$, and this signaling is modulated by deformation and applied load $(61,62)$.

The contractile apparatus is the most prominent structure in a muscle fiber, and may be a good marker for the deformation of the cell body. The interdigitating arrays of thick and thin filaments are rigidly immobilized by the M- and Z-disks, respectively, and the thick filaments are tethered by titin to the Z-disk. As the fiber lengthens, the filaments slide relative to each other. Titin binds both thick filaments and the Z-disk and is loaded and elongated as the sarcomere is extended $(41,63)$. There is some evidence to suggest that members of the ankyrin repeat protein (ARP) family can be displaced by stretch from titin to the nucleus (64), where they form complexes with transcription factors YB-1 and p53 $(64,65)$.

If any crossbridges are attached, the ease with which the A- and I- band slide will be reduced. Tension will develop in the myofilaments, the M- and Z-disks, and the molecules that anchor those structures to the extracellular matrix, while other structures, including titin, may be shielded from deformation. Both the thick and thin filaments are modestly extensible $(66,67)$, and the complex structures of the M- and Z-disks contain a number of biologically active molecules $(68,69)$, whose activity or localization may be modulated by mechanical signals $(70,71)$. The sarcomere matrix is anchored to the extracellular matrix via adhesions containing both integrins and dystroglycans $(72,73)$, and mechanical loading may trigger activation of signaling associated with those complexes.

Mechanics tells us that a bending deformation must be accompanied by bending moment, and that a shear force must accompany a non-uniform bending moment. In a muscle fiber, this means that myofibrils on the convex side of the fiber will be under slightly more tension than those on the concave side. It means that there will be a shear force perpendicular to the fiber axis. Both of these loads tend to separate adjacent myofibrils, yet the Z-disks of adjacent myofibrils maintain a consistent registry over a wide range of sarcomere lengths $(74,75)$. The intermediate filament desmin, which links adjacent Z-disks (76), is necessary for maintaining sarcomere registry during force generation (74), which suggests that desmin is subject to loading and elongation during cellular deformation, but it is not required for stretch induced growth (77).

Deformation of the sarcolemma appears to be highly localized, offering the possibility that even small deformations of a whole cell might induce dramatic but highly localized shape changes in the sarcolemma and cytoskeleton (75). Proteins within the sarcolemma, most notably stretch activated cation channels, can be deformed by membrane tension, allowing transsarcolemma currents and selective ion influx. Stretch and force generation are also associated with transient increases in sarcolemmal permeability $(78,79)$ consistent with 
physical disruption of the cell sarcolemma $(80,81)$. The sarcolemma itself is a tortuous structure, covered with deep folds and invaginations $(56,75,82)$. These structures become less apparent, in a discrete, quantal fashion, at longer sarcomere lengths $(75,83)$, and are associated with a delicate coating of caveolin (84) that may be a mechanism for converting mechanical deformation to kinase activation $(85,86)$. It has also been argued that cellular deformations can be accomplished without any change in cell surface area (43), which is parsimonious with the relative inextensibility of the lipid bilayer. This is not to suggest that the lipid bilayer is not deformable, but that the bilayer itself will support only a small amount of area dilation (87), relative to the extensibility of fibrous proteins.

\section{SIGNALING CASCADES}

These considerations reveal that there are many ways by which deformation of a myofiber might be converted to a biochemical signal. Far removed from that initial trigger, mechanical signaling has been associated with growth of the muscle, increased protein synthesis, activation of satellite cells, and release of growth factors $(12,13)$. The process overlaps with metabolic signaling, action potential signaling, and oxidative signaling, each of which can be modulated as part of the mechanical experience of the cell. Several major signaling cascades are involved in the prolonged response to mechanical signals, including PI-3K, various MAPKs, calcium, via calmodulin $(\mathrm{CaM})$ and calcineurin $(\mathrm{Cn})$, glycogen synthase kinase (GSK) and AMP activated kinase (AMPK) $(4,8,88-90)$. These cascades can be considered downstream effectors of the mechanotransduction event and review of them may reveal the threads of interaction.

\subsection{PI-3K}

A synthesis from the literature suggests that PI-3K plays a central role in the control of cell growth (Figure. 3). Canonical PI-3K is a dimeric inositol kinase, composed of an $85 \mathrm{kD}$ regulatory subunit (p85) and a $110 \mathrm{kD}$ catalytic subunit (p110), and acts by multiple routes to increase protein synthesis rates. The $\mathrm{p} 85$ subunit is recruited to activated receptor tyrosine kinases (RTKs) by an $s r c$ homology (SH2) domain, and this binding increases the kinase activity of the p110 subunit (91). Active PI-3K phosphorylates the 3' carbon of the inositol group of inositol phospholipids and, being most active towards PI-4,5- $\mathrm{P}_{2}$, increases the sarcolemma density of PI-3,4,5P . PIP3 recruits secondary kinases to the sarcolemma via their pleckstrin homology $(\mathrm{PH})$ domains, notably the serine/threonine kinases, phosphoinositidedependant kinase 1 (PDK1), integrin linked kinase (ILK), and protein kinase B (PKB; or Akt).

PDK1 phosphorylates members of the AGC family kinases, including PKB, the cyclic-AMP, and -GMP dependent kinases (PKA and PKG), and protein kinase $\mathrm{C}$ (PKC), but it is important to remember that its effect is spatially restricted by association with the sarcolemma. One of the key targets of PDK1 is the 70kD ribosomal S6 subunit kinase (p70S6K), which is phosphorylated on Thr229 by PDK1 (92). In turn, p70S6K phosphorylation of S6 ribosomal subunit increases the translational efficiency of mRNAs containing a 5' tract of oligopyrimidines (5'-TOP), which class includes much of the translational apparatus (93).

PKB activity depends on phosphorylation of Thr308 by PDK1 (94) and Ser473 by integrin linked kinase (ILK) (95), and canonically phosphorylates the mammalian target of rapamycin (mTOR) and glycogen synthase kinase (GSK3). The mTOR has been described as a nexus of translational control $(96,97)$, having been implicated in phosphorylation of the eIF4E binding protein (4E-BP or PHAS-1), p70S6K (98), and the eEF2 kinase (99). In vivo, elements of the PI-3K cascade are activated by insulin and IGF-1, by exercise, and by force generation and are modulated by nutrient and oxidative status $(4,96,100-102)$. In isolated muscle, mechanical stretch may lead to phosphorylation of PI-3K effectors, without phosphorylation of either PKB or mTOR (103). The observation that mTOR may be phosphorylated by p70S6K reminds us that this cascade is not a strict linear chain (104). There is good reason to believe that mTOR 
and its immediate effectors are key modulators of cellular growth $(96,100,101)$, but the mechanism by which mechanical loads activate the cascade is not clear. Some authors have demonstrated that stretch is associated with upregulation of IGF-1, a potent stimulator of PI-3K, and that conditioned media can mimic the effects of stretch $(7,105,106)$, suggesting that stretchinduced activation of PI-3K may be a secondary effect of growth factor release. Others have demonstrated that conditioned media is inadequate or that p70S6K activation is independent of PI-3K $(88,107)$. Some of this discrepancy is likely to derive from culture conditions, as it is not at all clear that the amount of IGF-1 or other diffusible factors released from cells during stretch is adequate to raise the concentration in conditioned media to biologically active levels. Some of this discrepancy may result from stretch conditions, as the results from uniaxial and biaxial stretch are often different $(52,107)$.

In addition to the stimulation of growth promoting processes, active PKB inhibits degenerative and apoptotic processes. Downstream effectors of PKB include the forkhead (FOXO) family of transcription factors (108), which are inactivated by $\mathrm{PKB}$, reducing the expression of muscle specific ubiquitin ligases muscle Ring-finger protein (MuRF) and muscle atrogen-like F-box protein (Mafbx) (109). Phosphorylation of PKB also leads to phosphorylation of BAD and suppression of apoptosis in endothelial cells (110).

One of the emerging interactions between the canonical, receptor activated PI-3K cascade and mechanical forces involves the integrin linked kinase (ILK) and the phosphatase and tensin homologue found on chromosome 10 (PTEN, also known as MMAC1). ILK binds the $\beta 1$ tails of ligand-bound integrins and $\mathrm{PIP}_{3}$, making it an attractive integrator of mechanical and hormonal signaling (111). PTEN, and the related SH2-containing inositol 5' phosphatase (SHIP), dephosphorylate PIP $_{3}$, antagonizing PI-3K (112,113), but also dephosphorylate FAK $(114,115)$. PTEN has been widely studied in the cancer field, where inactivating mutations are recognized as a trigger for cell transformation and unrestricted growth (112), and recent muscle specific downregulation of PTEN modulates insulin stimulated PKB phosphorylation in a fiber-type specific fashion (116). In the absence of PTEN, ILK activation is sufficient for Akt activation (117), suggesting that PI-3K and integrins cooperate in control of this cascade. Similarly, overexpression of PTEN inhibits ILK activity and promotes the disassembly of focal adhesions (115,118). PTEN has also been implicated as a negative regulator of mechanically induced mitogen activated protein (MAP) kinases $(119,120)$. Although regulation of PTEN activity is primarily at the transcriptional level (121), it appears to be inhibited by reversible oxidative modification (122), providing a mechanism to connect oxidative stress with mechanical signaling.

\subsection{MAP Kinases}

The MAP kinases are a diverse family canonically represented by the extracellular signal regulated kinases (ERK), c-jun N-Terminal kinases (JNK), and p38 MAPK, and characterized by a triplex cascade of MAP kinase kinase kinase (MEKK), MAP kinase kinase (MAPKK or MEK) and MAP kinase (123).

Receptor mediated activation of ERKs is initiated by recruitment of Shc, growth factor receptor bound protein 2 (Grb2), and son of sevenless (Sos) to phosphorylated tyrosine residues (124). This complex promotes nucleotide exchange on ras, and sequential phosphorylation of raf (MEKK), MEK, and ERK (125). Raf activation can also be accomplished by a multitude of mechanisms, including protein kinase $\mathrm{C}$ and phospholipase A2 (PLA2). Canonically, active ERK translocates to the nucleus and phosphorylates transcription factors, including c-Myc, cJun, c-Fos, and Elk-1, but can also phosphorylate biologically active cytoplasmic targets, including PLA2, p90S6K, and MAP kinase activated protein kinases (MAPKAP) (126). Following integrin ligation, shc can also be recruited to phosphorylated focal adhesion kinase (FAK), and PTEN blocks the cascade upstream of MEK (120). ERK is rapidly phosphorylated 
and activated following mechanical events $(89,127)$, but it also responds to oxidative stress (128), and to calcium via PKC. ERK, particularly p42/p44, have the potential to integrate mechanical, metabolic, and activity signals.

The canonical JNK cascade couples a receptor to MEKK activation by an adaptor complex composed of either ASK and TRAF or Mck and Rho. The mixed lineage kinases (MLK), ASK, and others then phosphorylate MKK7 or MKK4, which phosphorylate JNK (129). Substrates for JNK include AP-1 elements, JunD, and p53 (129), so there is a great deal of functional overlap between the JNK and ERK families. JNK is canonically activated by inflammatory cytokines and stress and is often associated with negative or degenerative cellular processes, including apoptosis (129). Integrin and PTEN signaling do not appear to influence JNK activation directly (120), although both JNK and ERK are strongly activated by stretch and force generation in muscle $(52,89,130)$.

The p38 MAP kinase family is more closely related to JNK than ERK, and the four p38 isoforms are phosphorylated by MEK3 or MEK6 in response to similar stimuli, including cytokines and environmental stressors (123). Substrates for p38 again include many AP-1 elements and MAPKAPK, but also the small heat shock proteins (131). There is some debate whether p38 isoforms are phosphorylated by mechanical signals $(89,103,127,130)$, but they do appear to participate in the control of cytoskeletal structure (131) and to be modulated by integrin dependent signaling (119).

\subsection{Phospholipases}

Phospholipid signaling plays an important role in mechanical signaling $(10,132)$.

Phospholipases (PL) cleave the polar head group from a membrane phospholipid, leaving a soluble second product and a modified lipid residue. The soluble product may be an active second messenger, and the lipid residue may anchor another enzyme to the membrane and increase its activity. They are classified as PLA, PLC, or PLD based on the site of cleavage.

There are three forms of PLA: the calcium independent iPLA, the secreted SPLA, and the calcium dependent, cytosolic cPLA. The A designation indicates that they cleave a fatty acid from the glycerol backbone. Most of them are specific for the fatty acid at the sn-2 position and are designated PLA2 (133). The cPLA2 family is particularly important in mechanical signaling because of their association with prostanoids (Figure 3 ). These enzymes highly favor phospholipids with arachidonic acid (AA) in the sn-2 position, and are a rate limiting step in the synthesis of eicosanoids including prostaglandin (PG) F2a, PGE2, PGI2, and thromboxane. Mechanical stimulation rapidly increases the activity of cPLA2, leading to synthesis and release of PGE2 and PGF2a $(132,134)$. PLA2 is recruited to the membrane and activated by calcium, and mechanical activation requires extracellular calcium, but not active depolarization. PGF2a synthesis can be inhibited by pertussis toxin (135), indicating a second level of control. The residual lysophosphatidylcholine has been implicated in exocytosis $(136,137)$, suggesting a mechanism by which stretch could trigger release of growth factors.

PGE2 is a potent inhibitor of protein synthesis, acting through the EP receptors. In normal skeletal muscle, the major receptor is EP3 (138), which is coupled to Gi and inhibition of adenylate cyclase. PGF2a binds most strongly to the FP receptor, triggering Gq and activating PLC (139). PGF2a treatment also leads to increased activity of PI-3K, ERK, and JNK, although the mechanism is less clear. PGF2a accumulates in muscle during stretch (10), is a potent stimulator of growth and differentiation $(140,141)$, and inhibitors of prostaglandin synthesis appear to block stretch induced growth in vitro $(10,134)$, but not necessarily in vivo $(142)$.

The phospholipase $\mathrm{C}$ family are specific for phosphatidylinositols, and cleave the sugar headgroup from the glycerol backbone, leaving a diacylglycerol (DAG) and a soluble inositol 
triphosphate (IP3) (143). IP3 canonically binds IP3 receptors in the sarco/endoplasmic reticulum, triggering localized release of calcium. The DAG, with calcium, recruit $\mathrm{C} 2$-domain containing proteins to the membrane, most notably the conventional protein kinases $\mathrm{C}$ (cPKC). PKC, in turn phosphorylates p53 (cell cycle arrest), raf (ERK), and phospholipase D, among others (144). Cyclic stretch activates PLC in multiple cell types $(132,145)$, apparently through a receptor mediated mechanism (145), and this could be a mechanism to amplify an influx of calcium from the extracellular space.

Most phospholipase D nonspecifically cleave phospholipids, leaving the phosphate group attached to the glycerol backbone to generate a phosphatidic acid and generally a free choline (146). PLD activity is increased after stretch, potentially activated by PKC, but also potentially by gangliosides or RhoA (146). In myotubes, stretch induced PLD activity is blocked by the G-protein inhibitor pertussis toxin (135), again suggesting that this is a relatively dependent aspect of the mechanical cascade. The phosphatidic acid can be subsequently processed to DAG or lysophosphatidic acid, which may extend the activation of PLA2 and PLC initiated processes (147).

\subsection{Calcium}

Calcium uniformly recognized as required for mechanical signaling $(14,148)$, which is not surprising, given the ubiquitous nature of calcium binding domains. Calcium is introduced to the mechanical response through at least three major mechanisms. The most obvious mechanism is the large calcium transient that accompanies an action potential and active force generation. Calcium concentrations during tetanic stimulation can rise as high as $5 \mathrm{uM}$ (15). Mechanical deformation of the cell may allow calcium influx through either stretch activated channels (149) or direct sarcolemma damage (150). PLC generated $\mathrm{IP}_{3}$ may trigger localized release of intracellular calcium. Although there are myriad calcium effectors, attention has become focused on calcineurin $(\mathrm{Cn})$, calmodulin dependent kinases (CaMK), and the calpains $(\mathrm{Cp})$.

Calcineurin is a calcium and calmodulin dependent phosphatase, also known as protein phosphatase 2B. Half maximal activation requires $1 \mathrm{uM} \mathrm{Ca} 2+$, with nanomolar calmodulin increasing both the calcium sensitivity and phosphatase activity (151). Cn dephosphorylates a number of targets, including phosphorylase kinase, protein phosphatase inhibitor-1 and the regulatory myosin light chain, although recent interest has focused on the NFAT family of transcription factors (152). Cn may also dephosphorylate MEF2 family members $(153,154)$, and transcription of muscle specific genes is certainly regulated by NFAT, MEF2, myogenic regulatory factors (MRFs) and interactions among these factors (153,155-157). NFAT/MEF2 dependent transcription has been difficult to decipher. Dephosphorylation of NFAT by $\mathrm{Cn}$ is required for nuclear translocation (158), but NFAT does not need to bind DNA to modulate transcription (159). Cn dependent dephosphorylation of MEF2 appears to increase the rate of MEF2 dependent transcription (154), as does $\mathrm{p} 38 / \mathrm{PKC} / \mathrm{CaMK}$ dependent phosphorylation (158). It appears that an intricate, residue specific pattern of MEF2 phosphorylation (160) modulates its interaction with class II histone deacetylases (HDAC) (161) and NFAT (162), and its transcriptional activity. Calcineurin certainly plays an important role in muscle development, hypertrophy, and mechanical signaling $(155,156,163,164)$, although the nature of that role is clouded by the complexity of its effectors $(165,166)$.

The calmodulin dependent kinases (CaMK), particularly CaMKII, appear to antagonize $\mathrm{Cn}$ signaling (167,168). Calmodulin, like calcineurin, binds Ca2+ with a Kd 1uM (169), but Ca2 +-CaM has a much higher affinity for CaMK than for Cn (170). CaMKII is notable for its ability to autophosphorylate and decouple from calcium, such that the combination of $\mathrm{Cn}$ and CaMKII can act as a sensor of integrated intracellular calcium (171). Electrical stimulation mimicking stereotypical fast and slow motor unit patterns has been used to modulate NFAT 
and HDAC4 nuclear transport on a time scale of tens of minutes to hours $(172,173)$. Thus, MEF2 dependent transcription appears to be sensitive to activity level through $\mathrm{Cn} / \mathrm{CaMK}$ and to purely mechanical stimuli through adhesion/p38.

The calpains ( $\mathrm{Cp}$ ) are calcium dependent proteases, divided in to the mu- and $\mathrm{m}$-calpains based on their calcium sensitivity $(174,175)$. Mu-Cp are generally activated by $\mathrm{Ca} 2+$ on the order of $10 \mathrm{uM}$, while M-Cp is activated by millimolar calcium. Both of these are distinctly higher than $\mathrm{Ca} 2+$ levels expected during normal activity, suggesting that they are activated by either highly localized signaling processes or by pathological events. Calpains specifically degrade structural proteins, including titin, filamin, and desmin, as an initial step towards disassembling the sarcomeric matrix (176). Calpains $1(\mathrm{mu})$ and $2(\mathrm{~m})$ participate in atrophic degeneration of muscle $(177,178)$, while calpains 2 and 3 appear to play a necessary role in myoblast fusion and differentiation $(179,180)$.

\subsection{Other signals}

The cascades mentioned above are by no means an exhaustive catalog of mechanisms associated with mechanically stimulated growth and development. They share the common feature of being primarily post-translational mechanisms, which can be immediately altered by stimuli as transient as a muscle twitch, making them particularly relevant to consideration of the perception of mechanical signals. The longer term response is also associated with upregulation and release of growth factors, including IGF-1 isoforms $(7,181)$, and with activation of satellite cells $(9,182)$. These processes are critical to the development or growth of the tissue, but do not seem to be among the direct sensors of mechanical stimuli. Likewise, the growth-promoting pathways described above are opposed by degradative mechanisms, the ubiquitin-proteasome pathway being of particular note $(183,184)$, but the participation of those mechanisms in the response to mechanical stimulation is not clear, and may be subordinate to PI-3K (109).

\section{PERSPECTIVE}

Clearly, a wide range of factors and cascades participate in mechanical signaling, and the challenge is to arrange them reasonably. We will try to do this in the context of focusing on consequences of cellular deformation specifically and try to separate consequences of depolarization and active force generation, although the latter are certainly powerful modulators of deformation induced signaling.

Several investigators have shown that inhibition of particular cascades is capable of disrupting the normal response to deformation. The increase in protein synthesis can be blocked by inhibition of pertussis toxin sensitive G-protein coupled receptors (135), prostaglandin synthesis (134), nitric oxide synthase (NOS) (185), Rho GTPases (186,187), basic fibroblast growth factor (bFGF) release (79), and stretch activated cation channels (102). Secretion of diffusible factors is clearly important for long-term growth, but it is likely to be a secondary effect of deformation, although a direct mechanical mechanism has been proposed for bFGF release (79). If stretch induces transient disruption of the cell membrane, it could be a mechanism for releasing cytoplasmic bFGF, and would allow the local influx of massive amounts of calcium. Since both calcium and bFGF appear to be necessary for stretch induced growth, this is a parsimonious mechanism (79).

Recent work in the Sheetz laboratory has shown that even permeabilized, "cytoskeletal ghosts" are capable of responding to stretch by recruitment and phosphorylation of focal adhesion molecules and small GTPases in fibroblasts $(62,188)$. As noted above, ILK and FAK can be potent stimulators of MAP kinase cascades and PI-3K, suggesting that deformation dependent, cell membrane independent activation of integrin mediated signaling may be sufficient for 
mechanotransduction. Integrins are well known to participate in the growth and development of muscle $(189,190)$, but whether this is an active or permissive role has not been clear. Finding that deformation of an adhesion complex is adequate to recruit active kinases suggests active participation.

Other structural molecules may serve parallel regulatory roles. The ankyrin repeat proteins (MARP, CARP, Ankrd2, etc) localize to either nucleus or titin, suggesting that these may be displaced from titin by deformation to act as transcriptional regulators $(64,65)$. Desmin, which appears to be a significant structural support (31), is not required for mechanotransduction (77). Multiple mechanical sensors may mediate a distinction between longitudinal and transverse growth signals. The increase in muscle fiber length stimulated by chronic stretch in vivo appears to be independent of innervation, and a muscle maintained in extension may increase in length even as it atrophies in girth $(191,192)$. Some investigators have suggested that the increase in muscle length might reflect a passive infilling of voids in the contractile apparatus opened by prolonged extension (193).

Deformation induced signaling is unquestionably different than signaling associated with active force generation. This is often demonstrated by comparing cellular events subsequent to force generation in combination with shortening or lengthening $(89,127,194)$, which turns out to be an extremely complex paradigm. As noted above, active force generation induces metabolic, calcium, and likely oxidative stresses in addition to the mechanical stress. The nonmechanical stressors do not appear to be adequate to reproduce the physiological response, as blocking the actin-myosin interaction reduces translational activity and gene expression $(195,196)$. Likewise, the application of identical force levels to active and passive muscles results in different responses (130). The varied aspects of the cellular environment have synergistic actions, and it is important to consider the entire milieu when evaluating the tissue response.

\section{Acknowledgements}

This work has been supported by grants from the National Institutes of Health (AR 48664 and AR48884).

\section{References}

1. Mitsumoto Y, Downey GP, Klip A. Stimulation of glucose transport in L6 muscle cells by long-term intermittent stretch-relaxation. FEBS Letters 1992;301:94-8. [PubMed: 1451794]

2. Yu KT, Czech MP. The type I insulin-like growth factor receptor mediates the rapid effects of multiplication-stimulating activity on membrane transport systems in rat soleus muscle. Journal of Biological Chemistry 1984;259:3090-5. [PubMed: 6321495]

3. Ihlemann J, Ploug T, Hellsten Y, Galbo H. Effect of stimulation frequency on contraction-induced glucose transport in rat skeletal muscle. American Journal of Physiology 2000;279:E862-7. [PubMed: 11001769]

4. Sakamoto K, Goodyear LJ. Invited review: intracellular signaling in contracting skeletal muscle. Journal of Applied Physiology 2002;93:369-83. [PubMed: 12070227]

5. Powers SK, Lennon SL. Analysis of cellular responses to free radicals: focus on exercise and skeletal muscle. Proceedings of the Nutrition Society 1999;58:1025-33. [PubMed: 10817171]

6. Reid MB. Invited Review: redox modulation of skeletal muscle contraction: what we know and what we don't. Journal of Applied Physiology 2001;90:724-31. [PubMed: 11160074]

7. Cheema U, Brown R, Mudera V, Yang SY, McGrouther G, Goldspink G. Mechanical signals and IGFI gene splicing in vitro in relation to development of skeletal muscle. Journal of Cellular Physiology 2005;202:67-75. [PubMed: 15389530]

8. Musi N, Yu H, Goodyear LJ. AMP-activated protein kinase regulation and action in skeletal muscle during exercise. Biochemical Society Transactions 2003;31:191-5. [PubMed: 12546683] 
9. Tatsumi R, Hattori A, Ikeuchi Y, Anderson JE, Allen RE. Release of hepatocyte growth factor from mechanically stretched skeletal muscle satellite cells and role of $\mathrm{pH}$ and nitric oxide. Molecular Biology of the Cell 2002;13:2909-18. [PubMed: 12181355]

10. Palmer RM, Reeds PJ, Atkinson T, Smith RH. The influence of changes in tension on protein synthesis and prostaglandin release in isolated rabbit muscles. Biochemical Journal 1983;214:1011-4. [PubMed: 6578794]

11. Huijing PA, Jaspers RT. Adaptation of muscle size and myofascial force transmission: a review and some new experimental results. Scandinavian Journal of Medicine \& Science in Sports 2005;15:349_ 80. [PubMed: 16293149]

12. Rennie MJ, Wackerhage H, Spangenburg EE, Booth FW. Control of the size of the human muscle mass. Annual Review of Physiology 2004;66:799-828.

13. Goldspink G. Changes in muscle mass and phenotype and the expression of autocrine and systemic growth factors by muscle in response to stretch and overload. Journal of Anatomy 1999;194:32334. [PubMed: 10386770]

14. Tidball JG. Mechanical signal transduction in skeletal muscle growth and adaptation. Journal of Applied Physiology 2005;98:1900-8. [PubMed: 15829723]

15. Konishi M, Watanabe M. Steady state relation between cytoplasmic free $\mathrm{Ca} 2+$ concentration and force in intact frog skeletal muscle fibers. Journal of General Physiology 1998;111:505-19. [PubMed: 9524135]

16. Patel TJ, Lieber RL. Force transmission in skeletal muscle: from actomyosin to external tendons. Exercise \& Sport Sciences Reviews 1997;25:321-63. [PubMed: 9213097]

17. Gibala MJ, Tarnopolsky MA, Graham TE. Tricarboxylic acid cycle intermediates in human muscle at rest and during prolonged cycling. Journal of Biological Chemistry 1997;272:E239-44.

18. Ra HJ, Picart C, Feng H, Sweeney HL, Discher DE. Muscle cell peeling from micropatterned collagen: direct probing of focal and molecular properties of matrix adhesion. Journal of Cell Science 1999;112 (Pt 10):1425-36. [PubMed: 10212137]

19. Huijing PA. Muscle as a collagen fiber reinforced composite: a review of force transmission in muscle and whole limb. Journal of Biomechanics 1999;32:329-45. [PubMed: 10213024]

20. Maas H, Baan GC, Huijing PA. Intermuscular interaction via myofascial force transmission: effects of tibialis anterior and extensor hallucis longus length on force transmission from rat extensor digitorum longus muscle. Journal of Biomechanics 2001;34:927-40. [PubMed: 11410176]

21. Huijing PA, Baan GC. Myofascial force transmission causes interaction between adjacent muscles and connective tissue: effects of blunt dissection and compartmental fasciotomy on length force characteristics of rat extensor digitorum longus muscle. Archives of Physiology \& Biochemistry 2001;109:97-109. [PubMed: 11780782]

22. Sinha S, Hodgson JA, Finni T, Lai AM, Grinstead J, Edgerton VR. Muscle kinematics during isometric contraction: development of phase contrast and spin tag techniques to study healthy and atrophied muscles. Journal of Magnetic Resonance Imaging 2004;20:1008-19. [PubMed: 15558560]

23. Finni T, Hodgson JA, Lai AM, Edgerton VR, Sinha S. Mapping of movement in the isometrically contracting human soleus muscle reveals details of its structural and functional complexity. Journal of Applied Physiology 2003;95:2128-33. [PubMed: 12857769]

24. Soman A, Hedrick TL, Biewener AA. Regional patterns of pectoralis fascicle strain in the pigeon Columba livia during level flight. Journal of Experimental Biology 2005;208:771-86. [PubMed: 15695768]

25. Zuurbier CJ, Huijing PA. Changes in geometry of actively shortening unipennate rat gastrocnemius muscle. Journal of Morphology 1993;218:167-80. [PubMed: 8263946]

26. Van Leeuwen JL, Spoor CW. Modelling the pressure and force equilibrium in unipennate muscles with in-line tendons. Philosophical Transactions of the Royal Society of London. Series B: Biological Sciences 1993;342:321-33.

27. Lemos RR, Epstein M, Herzog W, Wyvill B. A framework for structured modeling of skeletal muscle. Computer Methods in Biomechanics and Biomedical Engineering 2004;7:305-17. [PubMed: 15621651] 
28. Jenkyn TR, Koopman B, Huijing P, Lieber RL, Kaufman KR. Finite element model of intramuscular pressure during isometric contraction of skeletal muscle. Physics in Medicine \& Biology 2002;47:4043-61. [PubMed: 12476981]

29. Yucesoy CA, Koopman BH, Huijing PA, Grootenboer HJ. Three-dimensional finite element modeling of skeletal muscle using a two-domain approach: linked fiber-matrix mesh model. Journal of Biomechanics 2002;35:1253-62. [PubMed: 12163314]

30. Wang K, Ramirez-Mitchell R. A network of transverse and longitudinal intermediate filaments is associated with sarcomeres of adult vertebrate skeletal muscle. Journal of Cell Biology 1983;96:56270. [PubMed: 6682107]

31. Shah SB, Su FC, Jordan K, Milner DJ, Friden J, Capetanaki Y, Lieber RL. Evidence for increased myofibrillar mobility in desmin-null mouse skeletal muscle. Journal of Experimental Biology 2002;205:321-5. [PubMed: 11854369]

32. Trotter JA, Samora A, Baca J. Three-dimensional structure of the murine muscle-tendon junction. 1985;213:16-25.

33. Trotter JA, Corbett K, Avner BP. Structure and function of the murine muscle-tendon junction. 1981;201:293-302.

34. Street SF. Lateral transmission of tension in frog myofibers: a myofibrillar network and transverse cytoskeletal connections are possible transmitters. Journal of Cellular Physiology 1983;114:346-64. [PubMed: 6601109]

35. Julian FJ, Morgan DL. Intersarcomere dynamics during fixed-end tetanic contractions of frog muscle fibres. 1979;293:365-78.

36. Cleworth DR, Edman KA. Changes in sarcomere length during isometric tension development in frog skeletal muscle. Journal of Physiology 1972;227:1-17. [PubMed: 4539586]

37. Griffiths RI. Shortening of muscle fibres during stretch of the active cat medial gastrocnemius muscle: the role of tendon compliance. Journal of Physiology 1991;436:219-36. [PubMed: 2061831]

38. Butterfield TA, Leonard TR, Herzog W. Differential serial sarcomere number adaptations in knee extensor muscles of rats is contraction type dependent. Journal of Applied Physiology 2005;99:13528. [PubMed: 15947030]

39. Prado LG, Makarenko I, Andresen C, Kruger M, Opitz CA, Linke WA. Isoform diversity of giant proteins in relation to passive and active contractile properties of rabbit skeletal muscles. Journal of General Physiology 2005;126:461-80. [PubMed: 16230467]

40. Magid A, Law DJ. Myofibrils bear most of the resting tension in frog skeletal muscle. Science 1985;230:1280-2. [PubMed: 4071053]

41. Wang K, McCarter R, Wright J, Beverly J, Ramirez-Mitchell R. Regulation of skeletal muscle stiffness and elasticity by titin isoforms: a test of the segmental extension model of resting tension. Proceedings of the National Academy of Sciences of the United States of America 1991;88:71015. [PubMed: 1714586]

42. Purslow PP. Strain-induced reorientation of an intramuscular connective tissue network: implications for passive muscle elasticity. Journal of Biomechanics 1989;22:21-31. [PubMed: 2914969]

43. Purslow PP, Trotter JA. The morphology and mechanical properties of endomysium in series-fibred muscles: variations with muscle length. Journal of Muscle Research \& Cell Motility 1994;15:299_ 308. [PubMed: 7929795]

44. Gaylord RH. Fluid actuated motor system and stroking device. 1958

45. Chou CP, Hannaford B. Measurement and modeling of McKibben pneumatic artificial muscles. IEEE Transactions on Robotics and Automation 1996;12:90-102.

46. Ingber DE. Tensegrity: the architectural basis of cellular mechanotransduction. Annual Review of Physiology 1997;59:575-99.

47. Ingber DE. Opposing views on tensegrity as a structural framework for understanding cell mechanics. Journal of Applied Physiology 2000;89:1663-70. [PubMed: 11007610]

48. Lim TC. Elastic Stiffness of Three-Phase Composites by the Generalized Mechanics-of-Materials (GMM) Approach. Journal of Thermoplastic Composite Materials 2002;15:155-167.

49. Mansour H, de Tombe PP, Samarel AM, Russell B. Restoration of resting sarcomere length after uniaxial static strain is regulated by protein kinase Cepsilon and focal adhesion kinase. Circulation Research 2004;94:642-9. [PubMed: 14963000] 
50. Gullberg D, Fessler LI, Fessler JH. Differentiation, extracellular matrix synthesis, and integrin assembly by Drosophila embryo cells cultured on vitronectin and laminin substrates. Developmental Dynamics 1994;199:116-28. [PubMed: 7515725]

51. Clark CB, Burkholder TJ, Frangos JA. Uniaxial strain system to investigate strain rate regulation in vitro. Review of Scientific Instruments 2001;272:2415-2422.

52. Kumar A, Chaudhry I, Reid MB, Boriek AM. Distinct signaling pathways are activated in response to mechanical stress applied axially and transversely to skeletal muscle fibers. Journal of Biological Chemistry 2002;277:46493-503. [PubMed: 12221078]

53. Gilbert JA, Weinhold PS, Banes AJ, Link GW, Jones GL. Strain profiles for circular cell culture plates containing flexible surfaces employed to mechanically deform cells in vitro. Journal of Biomechanics 1994;27:1169-77. [PubMed: 7929466]

54. Lee AA, Delhaas T, Waldman LK, MacKenna DA, Villarreal FJ, McCulloch AD. An equibiaxial strain system for cultured cells. American Journal of Physiology 1996;271:C1400-8. [PubMed: 8897847]

55. Danowski BA, Imanaka-Yoshida K, Sanger JM, Sanger JW. Costameres are sites of force transmission to the substratum in adult rat cardiomyocytes. Journal of Cell Biology 1992;118:141120. [PubMed: 1522115]

56. Baum O, Planitzer G, Richter H, Gossrau R. Irregular costameres represent nitric oxide synthase-1positive sarcolemma invaginations enriched in contracted skeletal muscle fibres. Histochemical Journal 2000;32:743-51. [PubMed: 11254090]

57. Colognato H, Winkelmann DA, Yurchenco PD. Laminin polymerization induces a receptorcytoskeleton network. Journal of Cell Biology 1999;145:619-31. [PubMed: 10225961]

58. Cohn RD, Mayer U, Saher G, Herrmann R, van der Flier A, Sonnenberg A, Sorokin L, Voit T. Secondary reduction of alpha7B integrin in laminin alpha2 deficient congenital muscular dystrophy supports an additional transmembrane link in skeletal muscle. Journal of the Neurological Sciences 1999;163:140-52. [PubMed: 10371075]

59. Hilenski LL, Terracio L, Borg TK. Myofibrillar and cytoskeletal assembly in neonatal rat cardiac myocytes cultured on laminin and collagen. Cell \& Tissue Research 1991;264:577-87. [PubMed: 1907887]

60. Carson JA, Wei L. Integrin signaling's potential for mediating gene expression in hypertrophying skeletal muscle. Journal of Applied Physiology 2000;88:337-43. [PubMed: 10642399]

61. Iqbal J, Zaidi M. Molecular regulation of mechanotransduction. Biochemical \& Biophysical Research Communications 2005;328:751-5. [PubMed: 15694410]

62. Sawada Y, Sheetz MP. Force transduction by Triton cytoskeletons. Journal of Cell Biology 2002;156:609-15. [PubMed: 11839769]

63. Horowits R. The physiological role of titin in striated muscle. Reviews of Physiology Biochemistry \& Pharmacology 1999;138:57-96.

64. Miller MK, Bang ML, Witt CC, Labeit D, Trombitas C, Watanabe K, Granzier H, McElhinny AS, Gregorio CC, Labeit S. The muscle ankyrin repeat proteins: CARP, ankrd2/Arpp and DARP as a family of titin filament-based stress response molecules. Journal of Molecular Biology 2003;333:951-64. [PubMed: 14583192]

65. Kojic S, Medeot E, Guccione E, Krmac H, Zara I, Martinelli V, Valle G, Faulkner G. The Ankrd2 protein, a link between the sarcomere and the nucleus in skeletal muscle. Journal of Molecular Biology 2004;339:313-25. [PubMed: 15136035]

66. Suzuki S, Sugi H. Extensibility of the myofilaments in vertebrate skeletal muscle as revealed by stretching rigor muscle fibers. Journal of General Physiology 1983;81:531-46. [PubMed: 6682885]

67. Kojima H, Ishijima A, Yanagida T. Direct measurement of stiffness of single actin filaments with and without tropomyosin by in vitro nanomanipulation. Proceedings of the National Academy of Sciences of the United States of America 1994;91:12962-6. [PubMed: 7809155]

68. Sanger JW, Sanger JM. Fishing out proteins that bind to titin. Journal of Cell Biology 2001;154:214. [PubMed: 11448986]

69. Hayashi T, Arimura T, Itoh-Satoh M, Ueda K, Hohda S, Inagaki N, Takahashi M, Hori H, Yasunami M, Nishi H, Koga Y, Nakamura H, Matsuzaki M, Choi BY, Bae SW, You CW, Han KH, Park JE, Knoll R, Hoshijima M, Chien KR, Kimura A. Tcap gene mutations in hypertrophic cardiomyopathy 
and dilated cardiomyopathy. Journal of the American College of Cardiology 2004;44:2192-201. [PubMed: 15582318]

70. Knoll R, Hoshijima M, Hoffman HM, Person V, Lorenzen-Schmidt I, Bang ML, Hayashi T, Shiga N, Yasukawa H, Schaper W, McKenna W, Yokoyama M, Schork NJ, Omens JH, McCulloch AD, Kimura A, Gregorio CC, Poller W, Schaper J, Schultheiss HP, Chien KR. The cardiac mechanical stretch sensor machinery involves a $\mathrm{Z}$ disc complex that is defective in a subset of human dilated cardiomyopathy. Cell 2002;111:943-55. [PubMed: 12507422]

71. McGrath MJ, Mitchell CA, Coghill ID, Robinson PA, Brown S. Skeletal muscle LIM protein 1 (SLIM1/FHL1) induces alpha 5 beta 1-integrin-dependent myocyte elongation. American Journal of Physiology 2003;285:C1513-26. [PubMed: 12917103]

72. Anastasi G, Amato A, Tarone G, Vita G, Monici MC, Magaudda L, Brancaccio M, Sidoti A, Trimarchi F, Favaloro A, Cutroneo G. Distribution and localization of vinculin-talin-integrin system and dystrophin-glycoprotein complex in human skeletal muscle. Immunohistochemical study using confocal laser scanning microscopy. Cells Tissues Organs 2003;175:151-64. [PubMed: 14663158]

73. Yoshida T, Pan Y, Hanada H, Iwata Y, Shigekawa M. Bidirectional signaling between sarcoglycans and the integrin adhesion system in cultured L6 myocytes. Journal of Biological Chemistry 1998;273:1583-90. [PubMed: 9430699]

74. Shah SB, Davis J, Weisleder N, Kostavassili I, McCulloch AD, Ralston E, Capetanaki Y, Lieber RL. Structural and functional roles of desmin in mouse skeletal muscle during passive deformation. Biophysical Journal 2004;86:2993-3008. [PubMed: 15111414]

75. Dulhunty AF, Franzini-Armstrong C. The relative contributions of the folds and caveolae to the surface membrane of frog skeletal muscle fibres at different sarcomere lengths. Journal of Physiology 1975;250:513-39. [PubMed: 1080806]

76. Richardson FL, Stromer MH, Huiatt TW, Robson RM. Immunoelectron and immunofluorescence localization of desmin in mature avian muscles. 1981;26:91-101.

77. Shah SB, Peters D, Jordan KA, Milner DJ, Friden J, Capetanaki Y, Lieber RL. Sarcomere number regulation maintained after immobilization in desmin-null mouse skeletal muscle. Journal of Experimental Biology 2001;204:1703-10. [PubMed: 11316490]

78. Petrof BJ, Shrager JB, Stedman HH, Kelly AM, Sweeney HL. Dystrophin protects the sarcolemma from stresses developed during muscle contraction. Proceedings of the National Academy of Sciences of the United States of America 1993;90:3710-4. [PubMed: 8475120]

79. Clarke MS, Feeback DL. Mechanical load induces sarcoplasmic wounding and FGF release in differentiated human skeletal muscle cultures. FASEB Journal 1996;10:502-9. [PubMed: 8647349]

80. McNeil PL, Steinhardt RA. Plasma membrane disruption: repair, prevention, adaptation. Annual Review of Cell \& Developmental Biology 2003;19:697-731.

81. McNeil PL, Baker MM. Cell surface events during resealing visualized by scanning-electron microscopy. Cell \& Tissue Research 2001;304:141-6. [PubMed: 11383880]

82. Mobley BA, Eisenberg BR. Sizes of components in frog skeletal muscle measured by methods of stereology. Journal of General Physiology 1975;66:31-45. [PubMed: 1159401]

83. Prescott L, Brightman MW. The sarcolemma of Aplysia smooth muscle in freeze-fracture preparations. Tissue \& Cell 1976;8:248-58. [PubMed: 941133]

84. Sargiacomo M, Scherer PE, Tang Z, Kubler E, Song KS, Sanders MC, Lisanti MP. Oligomeric structure of caveolin: implications for caveolae membrane organization. Proceedings of the National Academy of Sciences of the United States of America 1995;92:9407-11. [PubMed: 7568142]

85. Kawabe J, Okumura S, Lee MC, Sadoshima J, Ishikawa Y. Translocation of caveolin regulates stretchinduced ERK activity in vascular smooth muscle cells. American journal of physiology 2004;286:H1845-52. [PubMed: 15072971]

86. Kawamura S, Miyamoto S, Brown JH. Initiation and transduction of stretch-induced RhoA and Rac1 activation through caveolae: cytoskeletal regulation of ERK translocation. Journal of Biological Chemistry 2003;278:31111-7. [PubMed: 12777392]

87. Kwok R, Evans E. Thermoelasticity of large lecithin bilayer vesicles. Biophysical Journal 1981;35:637-52. [PubMed: 7272454]

88. Hornberger TA, Stuppard R, Conley KE, Fedele MJ, Fiorotto ML, Chin ER, Esser KA. Mechanical stimuli regulate rapamycin-sensitive signalling by a phosphoinositide 3-kinase-, protein kinase B- 
and growth factor-independent mechanism. Biochemical Journal 2004;380:795-804. [PubMed: 15030312]

89. Martineau LC, Gardiner PF. Insight into skeletal muscle mechanotransduction: MAPK activation is quantitatively related to tension. Journal of Applied Physiology 2001;91:693-702. [PubMed: 11457783]

90. Rauch C, Loughna PT. Cyclosporin-A inhibits stretch-induced changes in myosin heavy chain expression in C2C12 skeletal muscle cells. Cell Biochemistry \& Function. 2004

91. Foukas LC, Okkenhaug K. Gene-targeting reveals physiological roles and complex regulation of the phosphoinositide 3-kinases. Archives of Biochemistry \& Biophysics 2003;414:13-8. [PubMed: 12745249]

92. Pullen N, Dennis PB, Andjelkovic M, Dufner A, Kozma SC, Hemmings BA, Thomas G. Phosphorylation and activation of p70s6k by PDK1. Science 1998;279:707-10. [PubMed: 9445476]

93. Pullen N, Thomas G. The modular phosphorylation and activation of p70s6k. FEBS Letters 1997;410:78-82. [PubMed: 9247127]

94. Alessi DR, James SR, Downes CP, Holmes AB, Gaffney PR, Reese CB, Cohen P. Characterization of a 3-phosphoinositide-dependent protein kinase which phosphorylates and activates protein kinase Balpha. Current Biology 1997:7, 261-9.

95. Persad S, Attwell S, Gray V, Mawji N, Deng JT, Leung D, Yan J, Sanghera J, Walsh MP, Dedhar S. Regulation of protein kinase B/Akt-serine 473 phosphorylation by integrin-linked kinase: critical roles for kinase activity and amino acids arginine 211 and serine 343. Journal of Biological Chemistry 2001;276:27462-9. [PubMed: 11313365]

96. Bodine SC, Stitt TN, Gonzalez M, Kline WO, Stover GL, Bauerlein R, Zlotchenko E, Scrimgeour A, Lawrence JC, Glass DJ, Yancopoulos GD. Akt/mTOR pathway is a crucial regulator of skeletal muscle hypertrophy and can prevent muscle atrophy in vivo. Nature Cell Biology 2001;3:1014-9.

97. Martin DE, Hall MN. The expanding TOR signaling network. Current Opinion in Cell Biology 2005;17:158-66. [PubMed: 15780592]

98. Hara K, Yonezawa K, Kozlowski MT, Sugimoto T, Andrabi K, Weng QP, Kasuga M, Nishimoto I, Avruch J. Regulation of eIF-4E BP1 phosphorylation by mTOR. Journal of Biological Chemistry 1997;272:26457-63. [PubMed: 9334222]

99. Browne GJ, Proud CG. A novel mTOR-regulated phosphorylation site in elongation factor 2 kinase modulates the activity of the kinase and its binding to calmodulin. Molecular \& Cellular Biology 2004;24:2986-97. [PubMed: 15024086]

100. Bolster DR, Kubica N, Crozier SJ, Williamson DL, Farrell PA, Kimball SR, Jefferson LS. Immediate response of mammalian target of rapamycin (mTOR)-mediated signalling following acute resistance exercise in rat skeletal muscle. Journal of Physiology 2003;553:213-20. [PubMed: 12937293]

101. Baar K, Esser K. Phosphorylation of p70(S6k) correlates with increased skeletal muscle mass following resistance exercise. American Journal of Physiology 1999;276:C120-7. [PubMed: 9886927]

102. Spangenburg EE, McBride TA. Inhibition of stretch-activated channels during eccentric muscle contraction attenuates p70S6K activation. Journal of Applied Physiology 2006;100:129-35. [PubMed: 16179399]

103. Hornberger TA, Chien S. Mechanical stimuli and nutrients regulate rapamycin-sensitive signaling through distinct mechanisms in skeletal muscle. Journal of Cellular Biochemistry. 2005

104. Chiang GG, Abraham RT. Phosphorylation of mammalian target of rapamycin (mTOR) at Ser-2448 is mediated by p70S6 kinase. Journal of Biological Chemistry 2005;280:25485-90. [PubMed: 15899889]

105. Baar K, Torgan CE, Kraus WE, Esser K. Autocrine phosphorylation of p70(S6k) in response to acute stretch in myotubes. Molecular Cell Biology Research Communications 2000;4:76-80. [PubMed: 11170836]

106. Perrone CE, Fenwick-Smith D, Vandenburgh HH. Collagen and stretch modulate autocrine secretion of insulin-like growth factor-1 and insulin-like growth factor binding proteins from differentiated skeletal muscle cells. Journal of Biological Chemistry 1995;270:2099-106. [PubMed: 7530717] 
107. Hornberger TA, Armstrong DD, Koh TJ, Burkholder TJ, Esser KA. Intracellular signaling specificity in response to uniaxial vs. multiaxial stretch: implications for mechanotransduction. American Journal of Physiology 2005;288:C185-94. [PubMed: 15371259]

108. Brunet A, Bonni A, Zigmond MJ, Lin MZ, Juo P, Hu LS, Anderson MJ, Arden KC, Blenis J, Greenberg ME. Akt promotes cell survival by phosphorylating and inhibiting a Forkhead transcription factor. Cell 1999;96:857-68. [PubMed: 10102273]

109. Sandri M, Sandri C, Gilbert A, Skurk C, Calabria E, Picard A, Walsh K, Schiaffino S, Lecker SH, Goldberg AL. Foxo transcription factors induce the atrophy-related ubiquitin ligase atrogin-1 and cause skeletal muscle atrophy. Cell 2004;117:399-412. [PubMed: 15109499]

110. Liu XM, Ensenat D, Wang H, Schafer AI, Durante W. Physiologic cyclic stretch inhibits apoptosis in vascular endothelium. FEBS Letters 2003;541:52-6. [PubMed: 12706818]

111. Delcommenne M, Tan C, Gray V, Rue L, Woodgett J, Dedhar S. Phosphoinositide-3-OH kinasedependent regulation of glycogen synthase kinase 3 and protein kinase B/AKT by the integrinlinked kinase. Proceedings of the National Academy of Sciences of the United States of America 1998;95:11211-6. [PubMed: 9736715]

112. Goberdhan DC, Wilson C. PTEN: tumour suppressor, multifunctional growth regulator and more. Human Molecular Genetics 2003;12(Spec No 2):R239-48. [PubMed: 12928488]

113. Leslie NR, Downes CP. PTEN function: how normal cells control it and tumour cells lose it. Biochemical Journal 2004;382:1-11. [PubMed: 15193142]

114. Tamura M, Gu J, Danen EH, Takino T, Miyamoto S, Yamada KM. PTEN interactions with focal adhesion kinase and suppression of the extracellular matrix-dependent phosphatidylinositol 3kinase/Akt cell survival pathway. Journal of Biological Chemistry 1999;274:20693-703. [PubMed: 10400703]

115. Tamura M, Gu J, Matsumoto K, Aota S, Parsons R, Yamada KM. Inhibition of cell migration, spreading, and focal adhesions by tumor suppressor PTEN. Science 1998;280:1614-7. [PubMed: 9616126]

116. Wijesekara N, Konrad D, Eweida M, Jefferies C, Liadis N, Giacca A, Crackower M, Suzuki A, Mak TW, Kahn CR, Klip A, Woo M. Muscle-specific Pten deletion protects against insulin resistance and diabetes. Molecular \& Cellular Biology 2005;25:1135-45. [PubMed: 15657439]

117. Persad S, Attwell S, Gray V, Delcommenne M, Troussard A, Sanghera J, Dedhar S. Inhibition of integrin-linked kinase (ILK) suppresses activation of protein kinase B/Akt and induces cell cycle arrest and apoptosis of PTEN-mutant prostate cancer cells. Proceedings of the National Academy of Sciences of the United States of America 2000;97:3207-12. [PubMed: 10716737]

118. Morimoto AM, Tomlinson MG, Nakatani K, Bolen JB, Roth RA, Herbst R. The MMAC1 tumor suppressor phosphatase inhibits phospholipase $\mathrm{C}$ and integrin-linked kinase activity. Oncogene 2000;19:200-9. [PubMed: 10644997]

119. Aikawa R, Nagai T, Kudoh S, Zou Y, Tanaka M, Tamura M, Akazawa H, Takano H, Nagai R, Komuro I. Integrins play a critical role in mechanical stress-induced p38 MAPK activation. Hypertension 2002;39:233-8. [PubMed: 11847190]

120. Gu J, Tamura M, Yamada KM. Tumor suppressor PTEN inhibits integrin- and growth factormediated mitogen-activated protein (MAP) kinase signaling pathways. Journal of Cell Biology 1998;143:1375-83. [PubMed: 9832564]

121. Mayo LD, Seo YR, Jackson MW, Smith ML, Rivera Guzman J, Korgaonkar CK, Donner DB. Phosphorylation of human p53 at serine 46 determines promoter selection and whether apoptosis is attenuated or amplified. Journal of Biological Chemistry 2005;280:25953-9. [PubMed: 15843377]

122. Leslie NR, Bennett D, Lindsay YE, Stewart H, Gray A, Downes CP. Redox regulation of PI 3-kinase signalling via inactivation of PTEN. EMBO Journal 2003;22:5501-10. [PubMed: 14532122]

123. Pearson G, Robinson F, Beers Gibson T, Xu BE, Karandikar M, Berman K, Cobb MH. Mitogenactivated protein (MAP) kinase pathways: regulation and physiological functions. Endocrine Reviews 2001;22:153-83. [PubMed: 11294822]

124. Vanderkuur JA, Butch ER, Waters SB, Pessin JE, Guan KL, Carter-Su C. Signaling molecules involved in coupling growth hormone receptor to mitogen-activated protein kinase activation. Endocrinology 1997;138:4301-7. [PubMed: 9322943] 
125. Macdonald SG, Crews CM, Wu L, Driller J, Clark R, Erikson RL, McCormick F. Reconstitution of the Raf-1-MEK-ERK signal transduction pathway in vitro. Molecular \& Cellular Biology 1993;13:6615-20. [PubMed: 8413257]

126. Davis RJ. Transcriptional regulation by MAP kinases. Molecular Reproduction \& Development 1995;42:459-67. [PubMed: 8607977]

127. Wretman C, Lionikas A, Widegren U, Lannergren J, Westerblad H, Henriksson J. Effects of concentric and eccentric contractions on phosphorylation of MAPK(erk1/2) and MAPK(p38) in isolated rat skeletal muscle. Journal of Physiology 2001;535:155-64. [PubMed: 11507166]

128. Adderley SR, Fitzgerald DJ. Oxidative damage of cardiomyocytes is limited by extracellular regulated kinases 1/2-mediated induction of cyclooxygenase-2. Journal of Biological Chemistry 1999;274:5038-46. [PubMed: 9988750]

129. Davis RJ. Signal transduction by the JNK group of MAP kinases. Cell 2000;103:239-52. [PubMed: 11057897]

130. Boppart MD, Hirshman MF, Sakamoto K, Fielding RA, Goodyear LJ. Static stretch increases c-Jun NH2-terminal kinase activity and p38 phosphorylation in rat skeletal muscle. American Journal of Physiology 2001;280:C352-8. [PubMed: 11208531]

131. Guay J, Lambert H, Gingras-Breton G, Lavoie JN, Huot J, Landry J. Regulation of actin filament dynamics by p38 map kinase-mediated phosphorylation of heat shock protein 27. Journal of Cell Science 1997;110(Pt 3):357-68. [PubMed: 9057088]

132. Vandenburgh HH, Shansky J, Karlisch P, Solerssi RL. Mechanical stimulation of skeletal muscle generates lipid-related second messengers by phospholipase activation. Journal of Cell Physiology 1993;155:63-71.

133. Chakraborti S. Phospholipase A(2) isoforms: a perspective. Cellular Signalling 2003;15:637-65. [PubMed: 12742226]

134. Vandenburgh HH, Hatfaludy S, Sohar I, Shansky J. Stretch-induced prostaglandins and protein turnover in cultured skeletal muscle. American Journal of Physiology 1990;259:C232-40. [PubMed: 2382700]

135. Vandenburgh HH, Shansky J, Solerssi R, Chromiak J. Mechanical stimulation of skeletal muscle increases prostaglandin $\mathrm{F} 2$ alpha production, cyclooxygenase activity, and cell growth by a pertussis toxin sensitive mechanism. Journal of Cellular Physiology 1995;163:285-94. [PubMed: 7706373]

136. Nagao T, Kubo T, Fujimoto R, Nishio H, Takeuchi T, Hata F. Ca(2+)-independent fusion of secretory granules with phospholipase A2-treated plasma membranes in vitro. Biochemical Journal 1995;307 (Pt 2):563-9. [PubMed: 7537492]

137. Juhl K, Hoy M, Olsen HL, Bokvist K, Efanov AM, Hoffmann EK, Gromada J. cPLA2alpha-evoked formation of arachidonic acid and lysophospholipids is required for exocytosis in mouse pancreatic beta-cells. American Journal of Physiology 2003;285:E73-81. [PubMed: 12644445]

138. Wang W, Andersson M, Lonnroth C, Svanberg E, Lundholm K. Prostaglandin E and prostacyclin receptor expression in tumor and host tissues from MCG 101-bearing mice: a model with prostanoid-related cachexia. International Journal of Cancer 2005;115:582-90.

139. Bos CL, Richel DJ, Ritsema T, Peppelenbosch MP, Versteeg HH. Prostanoids and prostanoid receptors in signal transduction. International Journal of Biochemistry \& Cell Biology 2004;36:1187-205. [PubMed: 15109566]

140. Horsley V, Pavlath GK. Prostaglandin F2(alpha) stimulates growth of skeletal muscle cells via an NFATC2-dependent pathway. Journal of Cell Biology 2003;161:111-8. [PubMed: 12695501]

141. Smith RH, Palmer RM, Reeds PJ. Protein synthesis in isolated rabbit forelimb muscles. The possible role of metabolites of arachidonic acid in the response to intermittent stretching. Biochemical Journal 1983;214:153-61. [PubMed: 6412693]

142. McMillan DN, Reeds PJ, Lobley GE, Palmer RM. Changes in protein turnover in hypertrophying plantaris muscles of rats: effect of fenbufen--an inhibitor of prostaglandin synthesis. Prostaglandins 1987;34:841-52. [PubMed: 2453073]

143. Rhee SG. Regulation of phosphoinositide-specific phospholipase C. Annual Review of Biochemistry 2001;70:281-312.

144. Liu WS, Heckman CA. The sevenfold way of PKC regulation. Cell Signaling 1998;10:529-42. 
145. Rosales OR, Isales CM, Barrett PQ, Brophy C, Sumpio BE. Exposure of endothelial cells to cyclic strain induces elevations of cytosolic $\mathrm{Ca} 2+$ concentration through mobilization of intracellular and extracellular pools. Biophysical Journal 1997;326(Pt 2):385-92.

146. Exton JH. Regulation of phospholipase D. Biochimica et Biophysica Acta 1999;1439:121-33. [PubMed: 10425390]

147. Dhalla NS, Xu YJ, Sheu SS, Tappia PS, Panagia V. Phosphatidic acid: a potential signal transducer for cardiac hypertrophy. Journal of Molecular \& Cellular Cardiology 1997;29:2865-71. [PubMed: 9405162]

148. Ruwhof C, van der Laarse A. Mechanical stress-induced cardiac hypertrophy: mechanisms and signal transduction pathways. Cardiovascular Research 2000;47:23-37. [PubMed: 10869527]

149. Yeung EW, Whitehead NP, Suchyna TM, Gottlieb PA, Sachs F, Allen DG. Effects of stretchactivated channel blockers on [Ca2+]i and muscle damage in the mdx mouse. Journal of Physiology 2005;562:367-80. [PubMed: 15528244]

150. Clarke MS, Khakee R, McNeil PL. Loss of cytoplasmic basic fibroblast growth factor from physiologically wounded myofibers of normal and dystrophic muscle. Journal of Cell Science 1993;106(Pt 1):121-33. [PubMed: 8270618]

151. Stewart AA, Ingebritsen TS, Manalan A, Klee CB, Cohen P. Discovery of a Ca2+- and calmodulindependent protein phosphatase: probable identity with calcineurin (CaM-BP80). FEBS Letters 1982;137:80-4. [PubMed: 6279434]

152. Olson EN, Williams RS. Remodeling muscles with calcineurin. Bioessays 2000;22:510-9. [PubMed: 10842305]

153. Ornatsky OI, Cox DM, Tangirala P, Andreucci JJ, Quinn ZA, Wrana JL, Prywes R, Yu YT, McDermott JC. Post-translational control of the MEF2A transcriptional regulatory protein. Nucleic Acids Res 1999;27:2646-54. [PubMed: 10373581]

154. Wu H, Rothermel B, Kanatous S, Rosenberg P, Naya FJ, Shelton JM, Hutcheson KA, DiMaio JM, Olson EN, Bassel-Duby R, Williams RS. Activation of MEF2 by muscle activity is mediated through a calcineurin-dependent pathway. EMBO Journal 2001;20:6414-23. [PubMed: 11707412]

155. Rauch C, Loughna PT. Static stretch promotes MEF2A nuclear translocation and expression of neonatal myosin heavy chain in $\mathrm{C} 2 \mathrm{C} 12$ myocytes in a calcineurin- and p38-dependent manner. American Journal of Physiology 2005;288:C593-605. [PubMed: 15483225]

156. de Angelis L, Zhao J, Andreucci JJ, Olson EN, Cossu G, McDermott JC. Regulation of vertebrate myotome development by the p38 MAP kinase-MEF2 signaling pathway. Developmental Biology 2005;283:171-9. [PubMed: 15890335]

157. Puri PL, Sartorelli V. Regulation of muscle regulatory factors by DNA-binding, interacting proteins, and post-transcriptional modifications. Journal of Cellular Physiology 2000;185:155-73. [PubMed: 11025438]

158. Rao A, Luo C, Hogan PG. Transcription factors of the NFAT family: regulation and function. Annual Review of Immunology 1997;15:707-47.

159. Chin ER, Olson EN, Richardson JA, Yang Q, Humphries C, Shelton JM, Wu H, Zhu W, BasselDuby R, Williams RS. A calcineurin-dependent transcriptional pathway controls skeletal muscle fiber type. Genes \& Development 1998;12:2499-509. [PubMed: 9716403]

160. Cox DM, Du M, Marback M, Yang EC, Chan J, Siu KW, McDermott JC. Phosphorylation motifs regulating the stability and function of myocyte enhancer factor 2A. Journal of Biological Chemistry 2003;278:15297-303. [PubMed: 12586839]

161. Borghi S, Molinari S, Razzini G, Parise F, Battini R, Ferrari S. The nuclear localization domain of the MEF2 family of transcription factors shows member-specific features and mediates the nuclear import of histone deacetylase 4. Journal of Cell Science 2001;114:4477-83. [PubMed: 11792813]

162. Pan F, Ye Z, Cheng L, Liu JO. Myocyte enhancer factor 2 mediates calcium-dependent transcription of the interleukin-2 gene in T lymphocytes: a calcium signaling module that is distinct from but collaborates with the nuclear factor of activated T cells (NFAT). Journal of Biological Chemistry 2004;279:14477-80. [PubMed: 14722108]

163. Dunn SE, Burns JL, Michel RN. Calcineurin is required for skeletal muscle hypertrophy. Journal of Biological Chemistry 1999;274:21908-12. [PubMed: 10419511] 
164. Parsons SA, Millay DP, Wilkins BJ, Bueno OF, Tsika GL, Neilson JR, Liberatore CM, Yutzey KE, Crabtree GR, Tsika RW, Molkentin JD. Genetic loss of calcineurin blocks mechanical overloadinduced skeletal muscle fiber type switching but not hypertrophy. Journal of Biological Chemistry 2004;279:26192-200. [PubMed: 15082723]

165. Dupont-Versteegden EE, Knox M, Gurley CM, Houle JD, Peterson CA. Maintenance of muscle mass is not dependent on the calcineurin-NFAT pathway. American Journal of Physiology 2002;282:C1387-95. [PubMed: 11997253]

166. Serrano AL, Murgia M, Pallafacchina G, Calabria E, Coniglio P, Lomo T, Schiaffino S. Calcineurin controls nerve activity-dependent specification of slow skeletal muscle fibers but not muscle growth. Proceedings of the National Academy of Sciences of the United States of America 2001;98:13108-13. [PubMed: 11606756]

167. Wen Z, Guirland C, Ming GL, Zheng JQ. A CaMKII/calcineurin switch controls the direction of $\mathrm{Ca}(2+)$-dependent growth cone guidance. Neuron 2004;43:835-46. [PubMed: 15363394]

168. Chin ER. Role of $\mathrm{Ca} 2+/$ calmodulin-dependent kinases in skeletal muscle plasticity. Journal of Applied Physiology 2005;99:414-23. [PubMed: 16020436]

169. Linse S, Helmersson A, Forsen S. Calcium binding to calmodulin and its globular domains. Journal of Biological Chemistry 1991;266:8050-4. [PubMed: 1902469]

170. Waxham MN, Tsai AL, Putkey JA. A mechanism for calmodulin (CaM) trapping by CaM-kinase II defined by a family of CaM-binding peptides. Journal of Biological Chemistry 1998;273:17579_ 84. [PubMed: 9651352]

171. De Koninck P, Schulman H. Sensitivity of CaM kinase II to the frequency of Ca2+ oscillations. Science 1998;279:227-30. [PubMed: 9422695]

172. Liu Y, Cseresnyes Z, Randall WR, Schneider MF. Activity-dependent nuclear translocation and intranuclear distribution of NFATc in adult skeletal muscle fibers. Journal of Cell Biology 2001;155:27-39. [PubMed: 11581284]

173. Liu Y, Randall WR, Schneider MF. Activity-dependent and -independent nuclear fluxes of HDAC4 mediated by different kinases in adult skeletal muscle. Journal of Cell Biology 2005;168:887-97. [PubMed: 15767461]

174. Tidball JG, Spencer MJ. Calpains and muscular dystrophies. International Journal of Biochemistry \& Cell Biology 2000;32:1-5. [PubMed: 10661889]

175. Goll DE, Thompson VF, Li H, Wei W, Cong J. The calpain system. Physiological Reviews 2003;83:731-801. [PubMed: 12843408]

176. Huff-Lonergan E, Mitsuhashi T, Beekman DD, Parrish FC Jr, Olson DG, Robson RM. Proteolysis of specific muscle structural proteins by mu-calpain at low $\mathrm{pH}$ and temperature is similar to degradation in postmortem bovine muscle. Journal of Animal Science 1996;74:993-1008. [PubMed: 8726731]

177. Tidball JG, Spencer MJ. Expression of a calpastatin transgene slows muscle wasting and obviates changes in myosin isoform expression during murine muscle disuse. Journal of Physiology 2002;545:819-28. [PubMed: 12482888]

178. Huang J, Forsberg NE. Role of calpain in skeletal-muscle protein degradation. Proceedings of the National Academy of Sciences of the United States of America 1998;95:12100-5. [PubMed: 9770446]

179. Kramerova I, Kudryashova E, Tidball JG, Spencer MJ. Null mutation of calpain 3 (p94) in mice causes abnormal sarcomere formation in vivo and in vitro. Human Molecular Genetics 2004;13:1373-88. [PubMed: 15138196]

180. Temm-Grove CJ, Wert D, Thompson VF, Allen RE, Goll DE. Microinjection of calpastatin inhibits fusion in myoblasts. Experimental Cell Research 1999;247:293-303. [PubMed: 10047471]

181. Yang S, Alnaqeeb M, Simpson H, Goldspink G. Cloning and characterization of an IGF-1 isoform expressed in skeletal muscle subjected to stretch. Journal of Muscle Research \& Cell Motility 1996;17:487-95. [PubMed: 8884603]

182. Adams GR, Caiozzo VJ, Haddad F, Baldwin KM. Cellular and molecular responses to increased skeletal muscle loading after irradiation. American Journal of Physiology 2002;283:C1182-95. [PubMed: 12225982] 
183. Bodine SC, Latres E, Baumhueter S, Lai VK, Nunez L, Clarke BA, Poueymirou WT, Panaro FJ, Na E, Dharmarajan K, Pan ZQ, Valenzuela DM, DeChiara TM, Stitt TN, Yancopoulos GD, Glass DJ. Identification of ubiquitin ligases required for skeletal muscle atrophy. Science 2001;294:17048. [PubMed: 11679633]

184. Glass DJ. Skeletal muscle hypertrophy and atrophy signaling pathways. International Journal of Biochemistry \& Cell Biology 2005;37:1974-84. [PubMed: 16087388]

185. Koh TJ, Tidball JG. Nitric oxide synthase inhibitors reduce sarcomere addition in rat skeletal muscle. Journal of Physiology 1999;519(Pt 1):189-96. [PubMed: 10432349]

186. Aikawa R, Komuro I, Yamazaki T, Zou Y, Kudoh S, Zhu W, Kadowaki T, Yazaki Y. Rho family small $\mathrm{G}$ proteins play critical roles in mechanical stress-induced hypertrophic responses in cardiac myocytes. Circulation Research 1999;84:458-66. [PubMed: 10066681]

187. Pan J, Singh US, Takahashi T, Oka Y, Palm-Leis A, Herbelin BS, Baker KM. PKC mediates cyclic stretch-induced cardiac hypertrophy through Rho family GTPases and mitogen-activated protein kinases in cardiomyocytes. Journal of Cellular Physiology 2005;202:536-53. [PubMed: 15316932]

188. Tamada M, Sheetz MP, Sawada Y. Activation of a signaling cascade by cytoskeleton stretch. Developmental Cell 2004;7:709-18. [PubMed: 15525532]

189. Sastry SK, Lakonishok M, Thomas DA, Muschler J, Horwitz AF. Integrin alpha subunit ratios, cytoplasmic domains, and growth factor synergy regulate muscle proliferation and differentiation. Journal of Cell Biology 1996;133:169-84. [PubMed: 8601606]

190. Huang Y, Li J, Zhang Y, Wu C. The roles of integrin-linked kinase in the regulation of myogenic differentiation. Journal of Cell Biology 2000;150:861-72. [PubMed: 10953009]

191. Williams PE, Goldspink G. The effect of denervation and dystrophy on the adaptation of sarcomere number to the functional length of the muscle in young and adult mice. Journal of Anatomy 1976;122:455-465. [PubMed: 1002614]

192. de la Tour EH, Tabary JC, Tabary C, Tardieu C. The respective roles of muscle length and muscle tension in sarcomere number adaptation of guinea-pig soleus muscle. 1979;75:589-92.

193. Dix DJ, Eisenberg BR. Myosin mRNA accumulation and myofibrillogenesis at the myotendinous junction of stretched muscle fibers. Journal of Cell Biology 1990;111:1885-94. [PubMed: 2229178]

194. Nader GA, Esser KA. Intracellular signaling specificity in skeletal muscle in response to different modes of exercise. Journal of Applied Physiology 2001;90:1936-42. [PubMed: 11299288]

195. Nikcevic G, Heidkamp MC, Perhonen M, Russell B. Mechanical activity in heart regulates translation of alpha-myosin heavy chain mRNA but not its localization. American Journal of Physiology 1999;276:H2013-9. [PubMed: 10362682]

196. Soeno Y, Shimada Y, Obinata T. BDM (2,3-butanedione monoxime), an inhibitor of myosin-actin interaction, suppresses myofibrillogenesis in skeletal muscle cells in culture. Cell \& Tissue Research 1999;295:307-16. [PubMed: 9931377] 


\section{A Isolated muscle B Uniaxial culture}
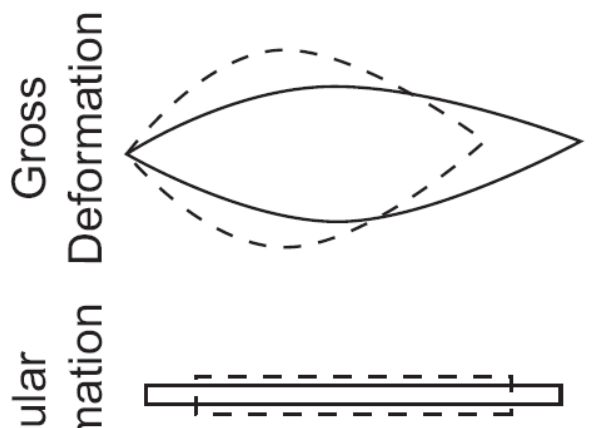
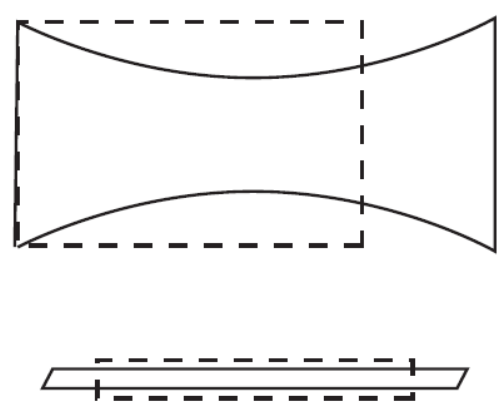

C Equibiaxial culture

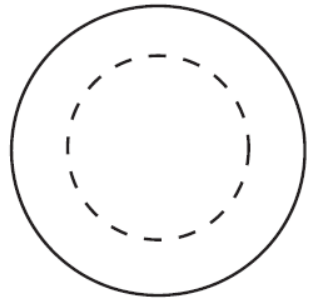

---------1
$1--------1$

Figure 1.

Exaggerated deformations of muscle (A), uniaxial tension (B), and biaxial tension (C), at the macroscopic level (upper row) and cellular level (lower row). The stress free state is illustrated by the dashed lines, and the deformed state by corresponding solid lines. Stretch of a fusiform muscle (A) causes elongation and internal stresses result in transverse constriction, the whole associated with a shape dependent distribution in shear strains. These strains occur in three dimensions, and do not require application of an outside compression. Uniaxial tension applied to an elastic membrane rigidly fixed at its ends (B) also causes elongation along that axis, constriction in the transverse direction and shear within the plane. The extent of transverse constriction is defined by the properties of the substrate and may impose additional outside strains on the adherent cells. The exact deformation depends on the orientation of the cell to the stretch axis, and the illustrated case is for a fiber perfectly aligned with the axis of stretch. Equibiaxial tension expands the cell equally in both planar dimensions, without shear (C). The cellular deformation is independent of orientation. 


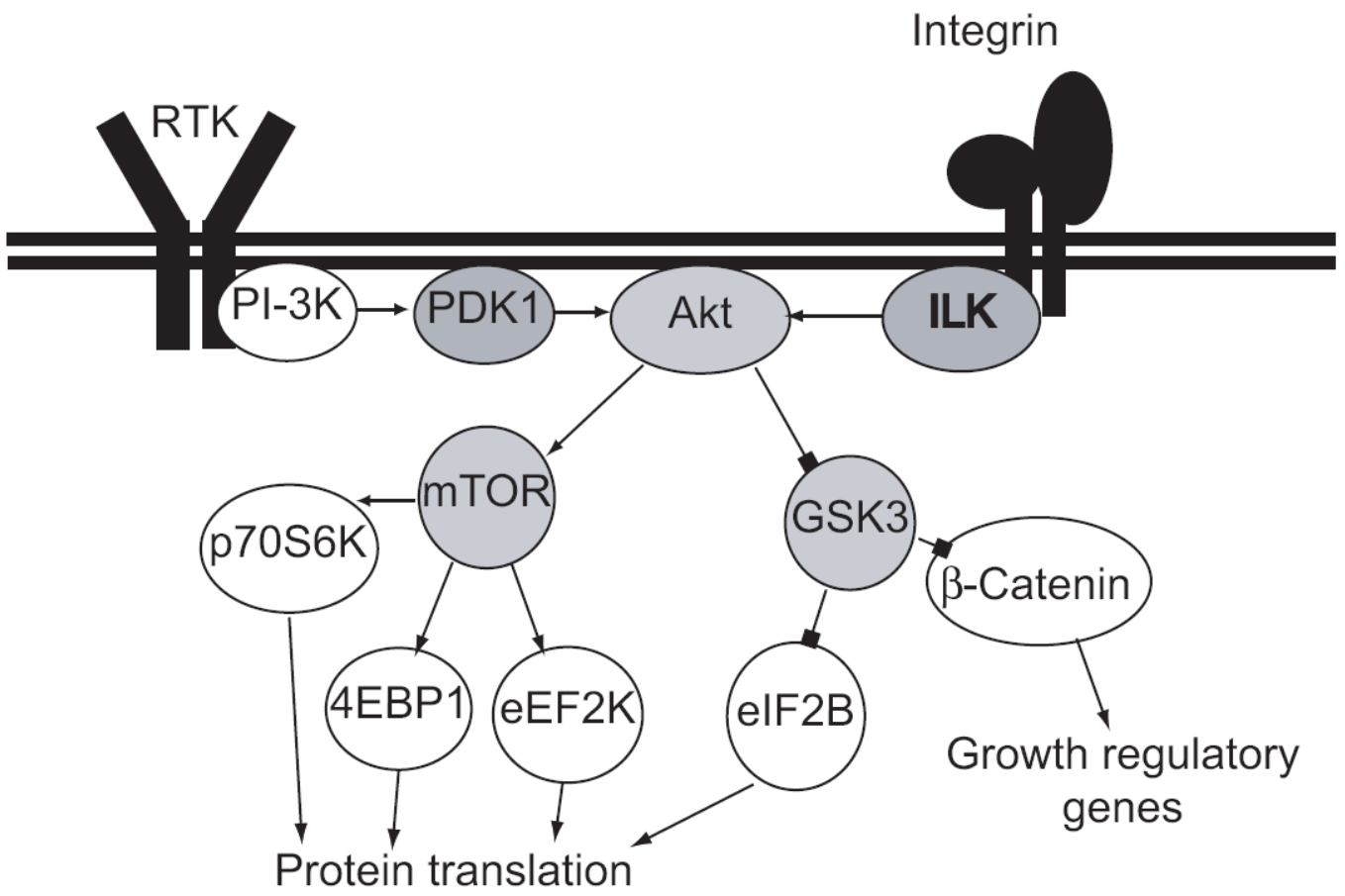

Figure 2.

Canonical signaling through the PI-3K cascade. PDK1 and ILK cooperate to activate Akt, which activates mTOR and inactivates GSK3, leading to increase rates of protein translation and increased expression of growth promoting genes. Arrowheads represent excitatory relationships; blockheads represent inhibitory relationships. The identity of the triggering receptor tyrosine kinase is not specified, because multiple receptors converge on this effector cascade 


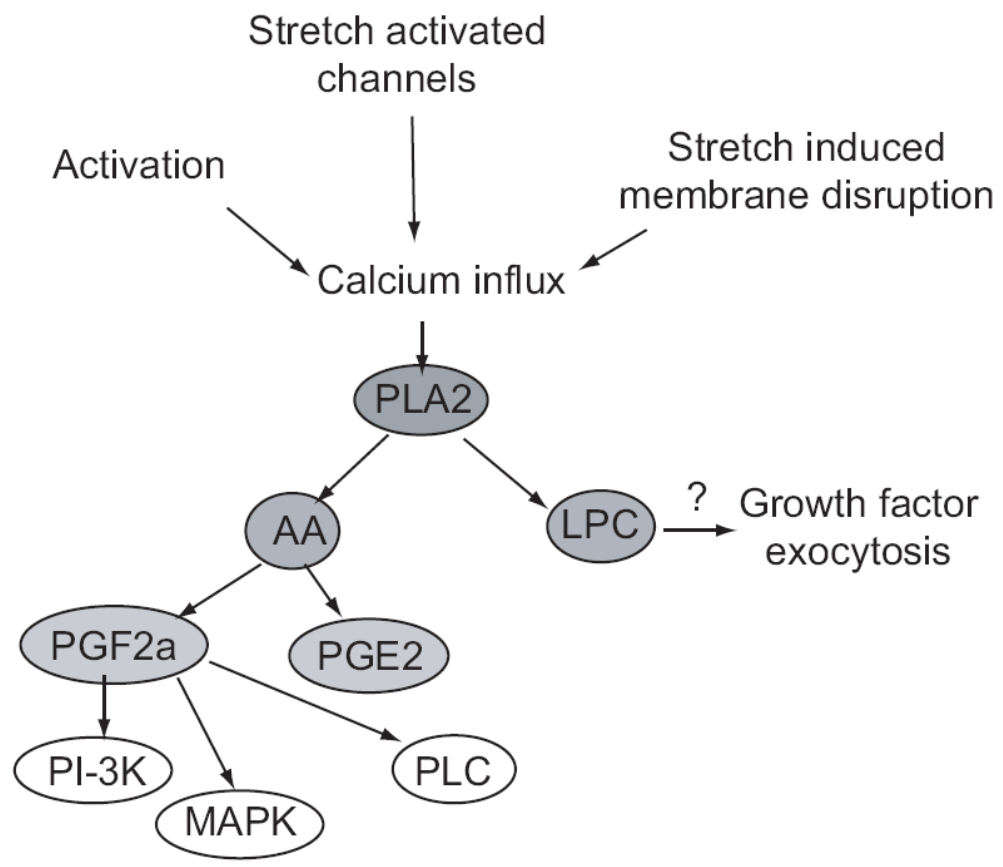

Figure 3.

Signaling through the PLA2 cascade. Mechanical or electrical stimulation increases intracellular calcium, which activates cPLA2. PLA2 generates AA and lysophosphatidylcholine (LPC), which may trigger release of growth factors. AA is metabolized to PGE2 and PGF2a, which acts through FP receptors to increase PI-3K, MAPK, and PLC activities, leading to growth. 